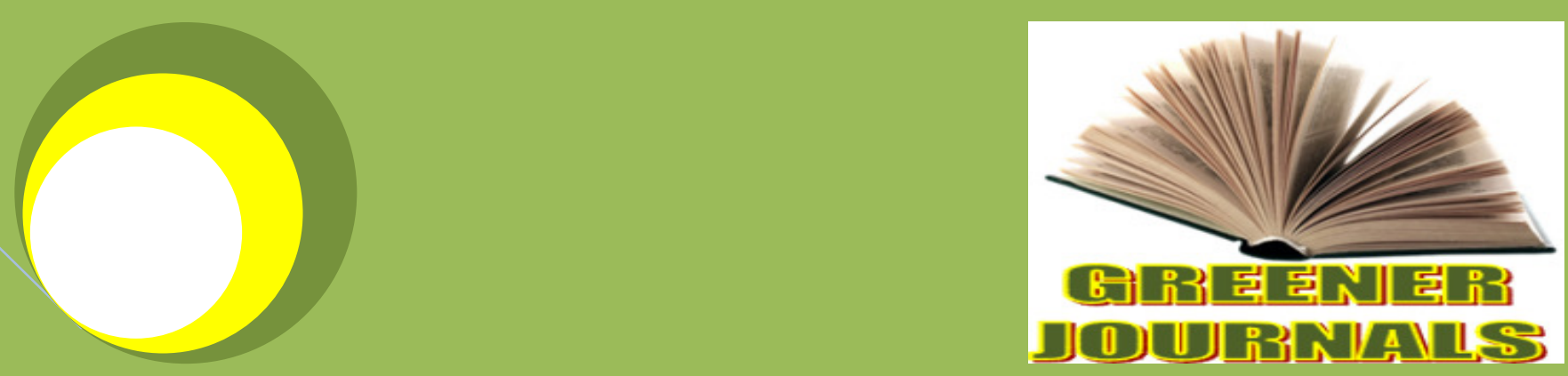

Greener lournal of Biólogical Sciènces

ISSN: 2276-7762 Impact Factor 2012 (UJRI): 0.7361 ICV 2012: 5.99

Bioaccumulation of some

Heavy Metals and Total

Hydrocarbon (THC) in the

Tissues of Periwinkle

(Tympanotonus Fuscatus

Var Radula) in the

Intertidal Regions of Qua

Iboe River Basin, Ibeno,

Akwa lbom State, Nigeria

By

Andem A. B.

Udofia U. U.

Okorafor K. A.

George U. U. 


\title{
Bioaccumulation of some Heavy Metals and Total Hydrocarbon (THC) in the Tissues of Periwinkle (Tympanotonus Fuscatus Var Radula) in the Intertidal Regions of Qua Iboe River Basin, Ibeno, Akwa Ibom State, Nigeria
}

\author{
*Andem A. B., Udofia U. U., Okorafor K. A. and George U. U. \\ Department of Zoology and Environmental Biology, University of Calabar, Cross River State, Nigeria.
}

*Corresponding Author's Email: a_andem010@yahoo.com, Tel: +2348060168081

\section{ABSTRACT}

The levels of some heavy metals and total hydrocarbon (THC) in the tissues of periwinkle (Tympanotomus fuscatus) from Qua Iboe River, Ibeno area in Akwa Ibom State were investigated. Three hundred samples of periwinkles were collected for a period of three months from two stations (Mkpanak-control and Itak Abasi-downstream) in the intertidal region of the River and were analyzed using Atomic Absorption Spectrophotometry for the determination of heavy metals and Soxhlet extraction gravimetric method was used in determination of total hydrocarbon. The mean levels of total hydrocarbon varied from $\mathbf{0 . 0 0 4 - 0 . 0 5 0 ~} \mathrm{mg} / \mathrm{g}$ and the mean level of heavy metals also varied: Cadmium (Cd), 0.043$0.53 \mathrm{mg} / \mathrm{g}$, Copper $(\mathrm{Cu}), 0.02-0.027 \mathrm{mg} / \mathrm{g}$, lead $(\mathrm{Pb}), 0.060-0.067 \mathrm{mg} / \mathrm{g}$, Mercury $(\mathrm{Hg}), 0.020-0.033 \mathrm{mg} / \mathrm{g}$, Nickel (Ni), 0.03$0.04 \mathrm{mg} / \mathrm{g}$ in all the stations. The levels of heavy metals and total hydrocarbon during the study period in all stations across the months did not show significant difference $(p>0.05$ ). This was attributed to the fact that, they were less industrial activities and close proximity of the stations to the major road where emissions from automobiles are abounded which is purely a residential area. These studies demonstrate that, the evidence of bioaccumulations of heavy metals and total hydrocarbons were below the recommended tolerable levels when compared to that of Federal Ministry of Environment. This implies that periwinkles from Qua lboe River, Ibeno are safer now than before as a food source for consumers who delight in this delicacy. However, constant monitoring of water bodies receiving effluents is emphasized in order to forestall cumulative effects of pollutants which may lead to sub-lethal consequences in the aquatic fauna and clinical poisoning to man.

Keywords: Bioaccumulation, Heavy Metals, Periwinkles, Intertidal Region, Nigeria. 


\section{INTRODUCTION}

Bio-accumulation means an increase in the concentration of a chemical or substance in a biological organism over time, compared to its concentration in the environment (DPR, 2002). Thus, understanding the dynamic process of bioaccumulation is very important in protecting human beings and other organisms from the adverse effects of chemical exposure and has become a critical consideration in the regulation of chemicals (DPR, 2002; OECD, 2003). Periwinkles are mass-consumer products constituting relatively cheap animal protein in Akwa-lbom State (Ekanem and Otti, 1997) and are one of the many delicacies in the Nigeria cuisines. Tympanotomus fuscatus is a common species of periwinkle found in the Ibeno River. Many aquatic organisms, for examples periwinkles have the ability to accumulate and bio-magnify contaminants like heavy metals, polycyclic aromatic hydrocarbons and total hydrocarbon in the environment. Aquatic organisms such as fish and Gastropods are capable of accumulating heavy metals in their living cells to concentrations much higher than those present in water, sediment and micro flora in their environment (Forstner and Wittmann, 1981). The presence of heavy metals in river, Lake or any aquatic environment can change both aquatic species diversity and ecosystems due to their toxicity and accumulative behaviour (Heath, 1987). It is also known that physiological and biochemical parameters in aquatic organisms' blood and tissues could change when exposed to heavy metals and other toxic substances exerting an extra stress on the organisms (Davies et al., 2006). Farkas et al. 2003 reported that the contaminant levels in the gastropods are far higher than that of the surrounding water and sediments. This is because many aquatic organisms are capable of accumulating or bio-concentrating contaminants for example, heavy metals and total hydrocarbon (THC) in their tissues. Bio-magnification of heavy metals in edible tissues of these organisms, for example Tympanotonus species could pose health hazards to consumers. In the Niger Delta, gastropods and bivalves play significant roles as cheap sources of protein (Dambo, 1992). The region has been exposed to decades of pollution from crude oil related and industrial activities. Studies on gastropods and bivalves such as Crasosterea species, Pachymelania species, Litorina species and Pugilina species from this area have revealed heavy burdens of trace metals (Obasohan and Oronsaye, 2000). The Significance of this research work was to carefully quantify the accumulated heavy metals in Tympanotonus fuscatus from Qua Iboe River Basin, Ibeno, Akwa Ibom State so as to ascertain their suitability for human consumption and aquaculture, also to create awareness that will provide information on the impact of petroleum exploitation on the aquatic environment.

\subsection{MATERIALS AND METHODS}

\subsection{Description of study area}

Ibeno is located in the south east of Nigeria and is a local government area of Akwa Ibom State. Ibeno town lies on the eastern side of Qua lboe River about $3 \mathrm{~km}$ from the river mouth between latitude $456^{\circ} \mathrm{N}$ and $7.97^{\circ} \mathrm{E}$ and longitude $7.40^{\circ} \mathrm{N}$ and $8.0^{\circ} \mathrm{E}$ (Figure 1) and is one of the largest fishing settlements on the Nigerian coast. The estuarine area of lbeno, the low lying terrain may be submerged occasionally during the months of June to October. The climate is typically tropical, hot and humid, with a long wet season lasting from March to October and a shorter dry season that lasts from November to February. The major land use types in the lbeno include Fishing, Oil exploitation, Forestry and Agriculture in the Coastal areas. 


\subsection{Sampling Stations}

Two sampling stations (1-2) were chosen along the shore of the river. The co-ordinates of the sampling stations were also taken using Geographic Positioning System (GPS) and approximate distances of the stations were calculated.

\section{Station 1}

This station is assumed to be the upstream (i.e. control station), Fishing activities is very minimal in this station. This station is in Mkpanak community located on the east bank of the Qua Iboe River, Ibeno local government area between Latitude: $445^{\circ} \mathrm{N}$; Longitude: $730^{\circ} \mathrm{E}$ at 15 feet altitude.

\section{Station 2}

This is a commercial station with a large market located at the River side, domestic wastes from human households is being emptied into the River. This is a landing site for fishermen and distribution to other sectors. The station is in Itak Abasi community located on the west bank of Qua lboe River at Atlantic coastline between Latitude: N7 $40^{\circ} \mathrm{N}$; Longitude: $818^{\circ} \mathrm{W}$ at 20 feet altitude.

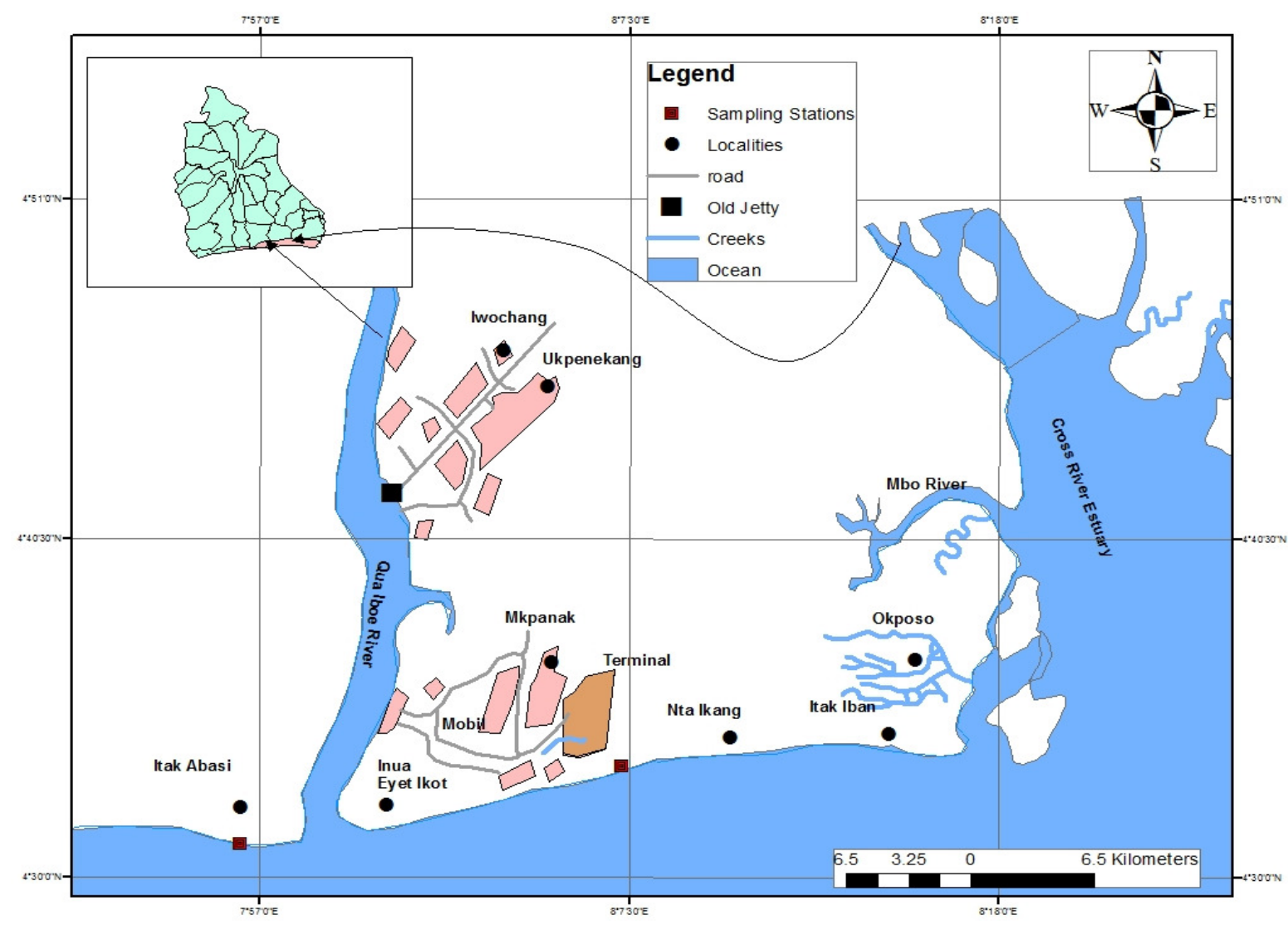

Figure 1: Map of Ibeno River Showing Sampling Stations 


\subsection{Collection of Periwinkle (Tympanotonus fuscatus) Samples}

Three hundred samples of Periwinkle were collected from September, 2012 to November, 2012 at two different sampling stations usually between 7:00am and 12.00noon.

\subsection{Determination of Heavy Metals Analysis}

Periwinkles were washed and frozen at $-5^{\circ} \mathrm{C}$ until they were ready for analysis. Later, periwinkles were deshelled and the soft tissues air-dried at room temperature for three weeks and were analyzed at the Department of Chemistry, University of Calabar. Tissues of periwinkles were ground to powder form, sieved, weighed and ashed at $77^{\circ} \mathrm{C}$ for two hours in a furnace. Ten grams of ashed periwinkle tissues were digested with $20 \mathrm{ml}$ of concentrated $\mathrm{HNO}_{3}$ and heavy metals such as Lead (Pb), Iron ( $\mathrm{Fe}$ ) and Cadmium (Cd), Mercury ( $\mathrm{Hg})$, Nickel (Ni) were determined using solar model-unicam 969 Atomic Absorption Spectrophotometer.

\subsection{Determination of Total Hydrocarbon}

The Soxhlet Extraction Gravimetric method was used for determination of petroleum hydrocarbon such as Total Hydrocarbon (THC). Fifty grams of air-dried and ground periwinkle tissues were extracted in Soxhlet Extractor for 8 hours using hexane acetone (60:40) cocktail solvent. Soluble metallic soaps were hydrolyzed by acidification. Oils and solids or viscous grease present were separated from liquid samples by filtration. After extraction, the residues after solvent evaporation were weighed to determine the oil and grease content. Compounds volatilized at or below $103^{\circ} \mathrm{C}$ were lost when filtered and dried.

\subsection{Statistical Analysis}

Data obtained were subjected to Descriptive Statistics and Simple student t-test, to test whether there is significant differences between the mean values of the two sampling stations.

\subsection{RESULT}

A summary of the Heavy metals and Total hydrocarbon in tissues of Tympanotomus fuscatus var radula of Qua Iboe River, Ibeno is shown in Table 1. Cadmium ranged between $0.043-0.53 \mathrm{mg} / \mathrm{g}$ with mean and standard error value of $0.048 \pm 0.004 \mathrm{mg} / \mathrm{g}$. Cadmium did not differ significantly between the stations $(p>0.05)$. Copper ranged between $0.020-0.027 \mathrm{mg} / \mathrm{g}$ with mean and standard error value of $0.024 \pm 0.003 \mathrm{mg} / \mathrm{g}$. Copper was also not significantly different between stations ( $p>0.05$ ). Lead ranged between $0.060-0.067 \mathrm{mg} / \mathrm{g}$ with mean and standard error value of $0.064 \pm 0.003 \mathrm{mg} / \mathrm{g}$. Lead was also not significantly different between stations ( $p>0.05$ ). Mercury ranged between $0.020-0.033 \mathrm{mg} / \mathrm{g}$ with mean and standard error value of $0.027 \pm 0.005 \mathrm{mg} / \mathrm{g}$. Copper was also not significantly different between stations ( $p>0.05$ ). Nickel ranged between $0.030-0.040 \mathrm{mg} / \mathrm{g}$ with mean and standard error value of $0.035 \pm 0.004 \mathrm{mg} / \mathrm{g}$. Nickel did not show significant difference between stations ( $p>0.05)$. Total hydrocarbon also ranged between $0.047-0.050 \mathrm{mg} / \mathrm{g}$ with mean and standard error value of $0.049 \pm 0.001 \mathrm{mg} / \mathrm{g}$. There were slight 
variation in concentration of Heavy metals and Total hydrocarbon observed across all stations during the study period.

Table 1: Mean variations and Simple T-test Analysis of some heavy metals and total hydrocarbon (THC) accumulated in tissues of Tympanotomus fuscatus var radula measured at the two stations in the intertidal regions of Qua Iboe River, Ibeno, Akwa Ibom State, Nigeria

\begin{tabular}{|c|c|c|c|c|c|c|}
\hline Study stations & $\begin{array}{l}\text { Station } 1 \\
\text { (Mkpanak) }\end{array}$ & $\begin{array}{l}\text { Station } 2 \\
\text { (Itak Abasi) }\end{array}$ & & & T-test Analysis & \\
\hline $\begin{array}{l}\text { Heavy metals/ } \\
\text { Hydrocarbon }\end{array}$ & Mean & Mean & Mean & $\begin{array}{l}\text { Standard } \\
\text { error }\end{array}$ & $\begin{array}{l}\text { Cal F-Value } \\
(p>0.05)\end{array}$ & $\begin{array}{l}\text { Tab F- Value } \\
(p>0.05)\end{array}$ \\
\hline Cadmium (mg/g) & $\begin{array}{l}0.043 \\
(0.03-0.05)\end{array}$ & $\begin{array}{l}0.053 \\
(0.05-0.06)\end{array}$ & $\begin{array}{l}0.048 \\
(0.043-0.053)\end{array}$ & 0.004 & 0.002 & 2.01 \\
\hline Copper $(\mathrm{mg} / \mathrm{g})$ & $\begin{array}{l}0.020 \\
(0.01-0.03)\end{array}$ & $\begin{array}{l}0.027 \\
(0.02-0.03)\end{array}$ & $\begin{array}{l}0.024 \\
(0.020-0.027)\end{array}$ & 0.003 & 0.0025 & 2.02 \\
\hline Lead $(\mathrm{mg} / \mathrm{g})$ & $\begin{array}{l}0.020 \\
(0.05-0.07)\end{array}$ & $\begin{array}{l}0.067 \\
(0.06-0.08)\end{array}$ & $\begin{array}{l}0.064 \\
(0.020-0.067)\end{array}$ & 0.003 & 0.0025 & 2.02 \\
\hline Mercury $(\mathrm{mg} / \mathrm{g})$ & $\begin{array}{l}0.020 \\
(0.01-0.03)\end{array}$ & $\begin{array}{l}0.033 \\
(0.02-0.05)\end{array}$ & $\begin{array}{l}0.027 \\
(0.020-0.033)\end{array}$ & 0.005 & 0.003 & 2.03 \\
\hline Nickel (mg/g) & $\begin{array}{l}0.04 \\
(0.03-0.05)\end{array}$ & $\begin{array}{l}0.03 \\
(0.02-0.04)\end{array}$ & $\begin{array}{l}0.035 \\
(0.04-0.03)\end{array}$ & 0.004 & 0.002 & 2.01 \\
\hline $\mathrm{THC}(\mathrm{Mg} / \mathrm{g})$ & $\begin{array}{l}0.047 \\
(0.03-0.06)\end{array}$ & $\begin{array}{l}0.05 \\
(0.05-0.05)\end{array}$ & $\begin{array}{l}0.049 \\
(0.047-0.050)\end{array}$ & 0.001 & 0.0005 & 1.01 \\
\hline
\end{tabular}

*Significant at $p>0.05$, Minimum - Maximum values in Parenthesis

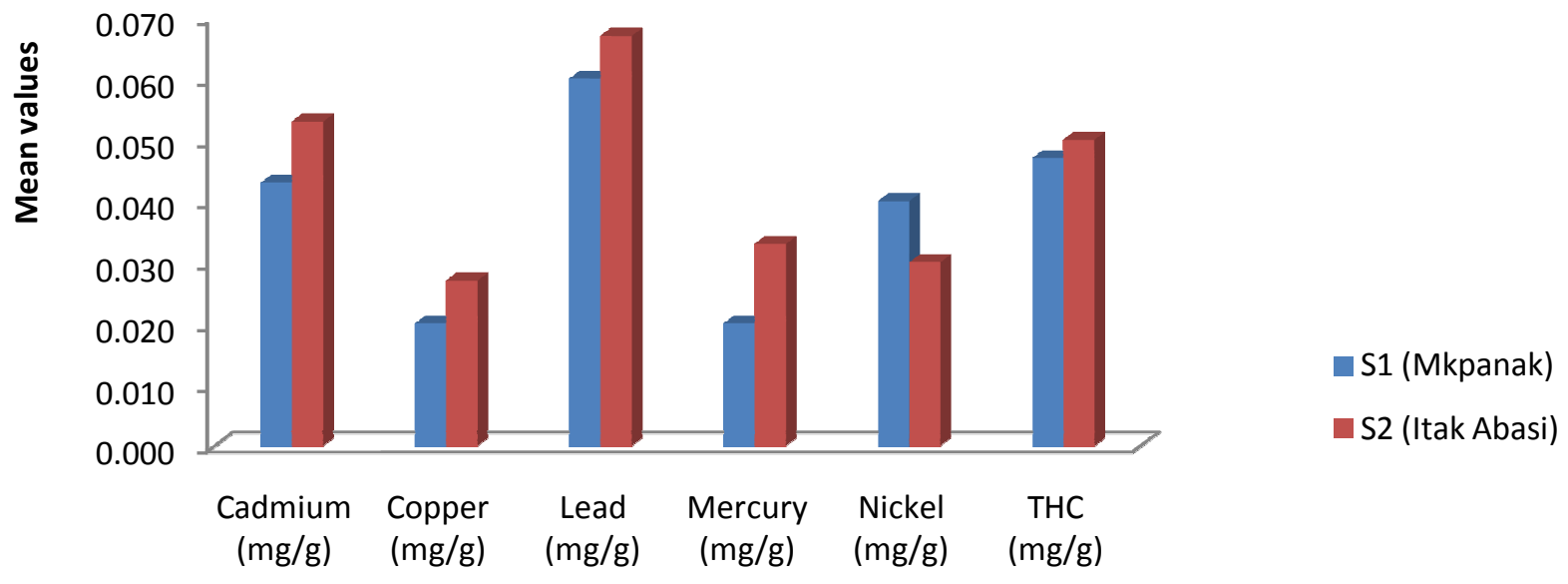

Heavy metals and Total hydrocarbon (THC)

Figure 2: Variation of some heavy metals and total hydrocarbon (THC) accumulated in the tissues of Tympanotomus fuscatus var radula in the intertidal region of Qua Iboe River. 


\subsection{DISCUSSION}

Knowledge of heavy metal concentrations in aquatic organisms is important due to the nature of management and human consumption of these species. Bioaccumulation of metals in periwinkles can be considered an index of metal pollution in aquatic bodies (Davies et al., 2006). The baseline concentrations of metal components in the unexposed test organisms at test initiation indicate generally low levels than observed for the tissues of the organisms after uptake of the effluent. However, the observed accumulation of heavy metals such Cadmium (Cd), Copper (Cu), Lead $(\mathrm{Pb})$, Mercury $(\mathrm{Hg})$ and Nickel $(\mathrm{Ni})$ in the test organisms could be from the sediment and were relatively low in this study. Certain factors may have influenced the differential uptake of metals in the test organisms. Low concentrations of total hydrocarbon (THC) were found in the test organisms. The levels of THC in the organisms' tissues could have been induced by uptake from the burrow pit sediment. Similar Finding was also observed by Davies et al., 2006. The differences in the level of heavy metals accumulated in the test organism, Tympanotonus fuscatus var radula could be attributed to the differences in their metabolic rates, feeding habits, age and sex (Kotze et al., 1999). Body size and health which are closely related to growth and metabolism has been shown to attribute most of the variations in heavy metals content of fishes (Moriarty et al., 1984).

Jack et al. (2005) noted that hydrocarbons take longer time to sink to the riverbed and that marine organisms accumulate hydrocarbons due to their sedentary and bottom feeding habit. According to Canterford et al. (1978), it is useful to express results in terms of bio-concentration factor (BCF) when comparing the order of uptake of metals. In this study, bio-concentration potentials were very low and varied with the mean concentration of heavy metals and total hydrocarbon (THC). However, the observed BCF indicates that periwinkles have potential to concentrate contaminants in their soft tissues (Ademoroti, 1996; Eja et al., 2003). The results from this study agreed with those obtained by Davies et al., (2006). Heavy metal tested indicates a low level of bioaccumulation in the tissues of the organisms. From this study, the result of heavy metals such as Cadmium (Cd), Copper ( $\mathrm{Cu})$, Lead (Pb), Mercury $(\mathrm{Hg})$, Nickel $(\mathrm{Ni})$ and total hydrocarbon $(\mathrm{THC})$ obtained from test organism, Tympanotonus fuscatus var radula were below acceptable limit.

This study demonstrated evidence of bioaccumulation of total hydrocarbons (THC) and some heavy metals in the tissues of periwinkles (Tympanotomus fuscatus var radula from Qua lboe River, Ibeno. Levels were however, observed to be below the recommended tolerance levels (Davies et al, 2006). The values obtained in this study were also lower than those reported in previous study which was suggestive of sub-lethal toxicity in humans (USEPA, 1986; Sharp, 1987 and Ayenimo et al., 2005). The results of this study show imminent problems of contamination in Qua lboe River, Ibeno if control measures are not put in place. This emphasizes the importance of constant monitoring of rivers and other water bodies receiving effluents in order to forestall cumulative effects of pollution in the river which may lead to sub lethal consequences in the aquatic fauna and clinical poisoning to man.

\subsection{CONCLUSION}

Tympanotomus fuscatus var radula could have the tendency to bio-accumulate with preferences for some heavy metals and total hydrocarbon (THC) depending on the ecological area. This could further demonstrate that the organism possesses bio-indicator attributes for monitoring metals in the River. 


\section{REFERENCES}

Ademoroti, C. M. A. (1996). Environmental chemistry and toxicology. Foludex Press Ltd, Ibadan, 217p.

Ayenimo, J.G., C. A. Adeyinwo, I. A. Amoo and F. I. Odukudu (2005). A preliminary investigation of heavy metals in periwinkles from Warri River, Nigeria. Journal of Applied Science, 5(5): 813 - 815.

Canterford, G.S., A. S Bichanan and S. C. Ducker (1978). Accumulation of heavy metals by the marine diatom Ditylum brightrelli (West) Grunow. Australia Journal of Marine freshwater Resources, 29:611-622.Department of Petroleum Resources (DPR) (2002). Environmental guidelines and standards for the petroleum industry in Nigeria (EGASPIN) Revised Edition.

Davies, O.A., M. E. Allison and H. S. Uyi (2006). Bioaccumulation of heavy metals in water, sediment and periwinkle (Tympanotonus fuscatus) from the Elechi Creek, Niger-Delta, Nigeria. African Journal of Biotechnology, 5:968973.

Dambo, W. B. (1992). Tolerance of the Periwinkles, Pachymelania aurita (Muller) and Tympanotonus fuscatus (Linne) to refined Oils. Environmental Pollution, 79:293-296.

Eja, M.E., O. R. Ogri and G. E. Arikpo (2003). Bio-concentration of heavy metals in surface sediments from the Great Kwa Rivers Estuary, Calabar, South Eastern Nigeria. Nigerian Journal of Environmental Sociology, 2:247-256.

Ekanem, E.O and B. N. Otti (1997). Total plate count and coli form levels in Nigeria periwinkles from fresh brackish water. Food Control, 8:81-89.

Farkas, A., I. Salánki, T. Kamardina and K. S. Rózsa (2003). Molluscs in biological monitoring of water quality. Toxicological Lattice, 140/141:403-410.

Jack, I.R., J. K. Fekarurhoho., F. U. Igwe and K. korosaye- Orubite (2005). Determination of total hydrocarbon levels in some marine organisms from some towns within the Rivers State of Nigeria. Journal of Applied Sciences and Environmental Management, 9(3): 59-61.

Obasohan, E. E and J. A.O. Oronsaye (2000). Heavy metals in water, sediments and some important fish species form Ikpoba River, Benin City, Nigeria. Journal of Applied Science and Environmental Management, 4(2): 63-68. Organization for Economic Cooperation and Development, (OECD) (2003). Environment, health and safety publications series on pesticides persistent, bio accumulative and toxic pesticides in OECD Member countries results of survey on data requirements and risk assessment approaches, 15: $1-67$.

Sharp, D.S., C. E. Becker and A. H. Smith (1987). Chronic low-level lend exposure: its role in the pathogenesis of hypertension. Medical Toxicology, 2: 210-232.

United States Environmental Protection Agency (USEPA) (1986). Biological indicators of watershed health. Available at $h t t p: / / w w w . e p a . g o v /$ Last modified January, 1987. 